\title{
Empowering Women? An Assessment of International Gender Policies in Bosnia
}

\section{Vanessa Pupavac}

School of Politics and International Relations

University of Nottingham

vanessa.pupavac@nottingham.ac.uk

A final proofed version of this article was published in

Vanessa Pupavac (2005) 'Empowering Women? An Assessment of International Gender Policies in Bosnia'. International Peacekeeping, Vol. 12 (3), pp. 391-405.

Article reprinted as chapter in David Chander (ed.) Peace without politics? Ten Years of International State-Building in Bosnia. London: Routledge, pp. 85-99

\begin{abstract}
International policy-making promises to empower women in Bosnia through encouraging their participation in the political process, giving them voice in civil society and through providing enhanced opportunities for economic independence. This paper challenges these claims, suggesting that while a narrow echelon of young middle class urban professionals have benefited from international gender approaches, the prospects for ordinary Bosnian women have not. First, the paper considers international attempts to promote the political empowerment of women through quota mechanisms and support for women's organisations operating in civil society. Secondly, the paper considers international policies intended to further the economic empowerment of women and how these relate to broader neo-liberal prescriptions for the post-war state. It concludes that international policies, in both the political and economic realms, contain fundamental limitations which look likely to frustrate the long-term advancement of women in Bosnia.
\end{abstract}

\section{Introduction}

This essay considers international gender policies and prospects they offer for the women of Bosnia (BiH) moving beyond post-conflict stabilization. Gender empowerment has become a standard tool of international peacebuilding in postconflict societies and $\mathrm{BiH}$ is no exception in this respect. Maximising the public role of women, whether as voters, journalists, political representatives or women's organisations is viewed as useful to undermine the power of nationalist parties and promote a more tolerant non-violent, political culture. Voter education, gender quotas, media training and broadening the political role of women's organisations have been pursued in numerous initiatives.

The Dayton settlement itself did not address the issue of gender, but considerable international attention has been given to the issue since then. To pursue gender empowerment more systematically, a Gender Co-ordination Group was established, chaired by the OHR, with representatives from the OSCE, OHCHR (Office of the High Commission for Human Rights), the International Human Rights Law Group and other international organisations. Its remit includes implementing the 
Convention on the Elimination of Discrimination against Women (CEDAW) and integrating the gender dimension into 'national legislation, public policies, programmes and projects'. ${ }^{2}$ A complimentary project, Gender Equity and Equality Project (GEEP) is supported by the Finnish government and operates through the Gender Centre of the Federation of Bosnia and Herzegovina (FBiH) and the Gender Centre of Republika Srpska (RS). ${ }^{2}$ Both projects helped sponsor a Law on Gender Equality, passed in $2003,{ }^{3}$ codifying international gender thinking and building on ad hoc measures such as electoral gender quotas.

The Law on Gender Equality has been followed up by a two-year $\$ 400,000$ project dedicated to its implementation supported by UNDP as the lead international organisation together with UNICEF, OHCHR, UNFPA and the ILO under the UN Gender Group. Importantly they have been working with the Ministry for Human Rights and Refugees (MHRR), the Entity Gender Centres and NGOs to establish a state-level gender agency. Initiatives also include gender awareness campaigns and 'training of trainers (judges, teachers, NGO officials, etc)' and other capacity building activities addressing gender equality and the elimination of gender-based violence. ${ }^{4}$ Meanwhile international microcredit programmes have often been directed towards women. The UNDP and other international organisations are keen to emphasise how their own programmes incorporate a gender dimension and how they strive towards a gender balance among their own employees. ${ }^{5}$

Below I consider international policies intended to politically empower women, analysing the impact of the quota system for appointment to government bodies and for political party candidate lists, and then go on to consider the role of internationally-funded in women's groups in political advocacy. The following section considers international strategy aimed at enhancing the economic empowerment of women, focusing on the rise of micro-credit initiatives and the encouragement of small businesses.

\section{Political empowerment?}

International gender policy has sought to redress discrimination against women in the political sphere. The war's impact on the number of female political representatives has been dramatic. Before the war, apparently 24.1 percent of the representatives in the Assembly of the Republic of Bosnia and Herzegovina and 17.3 percent of the representatives in the municipal assemblies were women. ${ }^{6}$ However, the number of women in parliament sharply plummeted in the first Bosnian elections held after the war. Women's strong presence in the NGO sector failed to translate into greater political representation. To cite just one figure, a solitary woman gained a seat out of the 42 seats in the Bosnian House of Representatives. ${ }^{7}$ Concern too has been expressed that economic crisis and war have undermined women's participation in the workplace. Large-scale unemployment, it is feared, has encouraged thinking receptive to a more gendered division of labour along with the ethnicised divisions.

These reversals have encouraged international officials to adopt a more proactive approach. The Law on Gender Equality does not confine itself to outlawing gender-based discrimination, direct or indirect. Instead the law incorporates an affirmative approach requiring gender parity in the allocation of public posts. Crucially Article 15 sets out the principle of equal gender representation in public life:

State and local authority bodies, corporate management bodies, political parties and other non-profit organizations shall ensure and promote equal 
representation on the basis of gender in management and the decisionmaking process...[T] he percentage of the sexes in government bodies at all levels, including the judiciary, legislature and executive, as well as all other public services, committees, boards, and bodies representing the state at the international level, shall as a rule reflect the equal gender representation (emphasis added). ${ }^{8}$

The requirement for equal gender representation has huge implications for public life in $\mathrm{BiH}$. Post-conflict $\mathrm{BiH}$ is effectively expected to implement more radical fast track measures than Britain, the High Representative Paddy Ashdown's own state, or the incremental track deployed in the Scandinavian countries. ${ }^{9}$ Britain would have difficulty in demonstrating equal gender representation at any level let alone at all levels of government and the public services. British government bodies, public services, private sector institutions and corporations would fall foul of this article. Moreover, the principle of gender parity compliments constitutional provisions codifying ethnic representation in public life. Consequently gender parity will have to be implemented taking into account the extensive quota requirements which exist for ethnic representation. Achieving gender parity and the required ethnic representation would only be possible with complex bureaucratic planning.

The Law on Gender Equality builds on various affirmative action initiatives seeking to challenge the political and cultural marginalisation of women. A Women in Politics programme was set up by the OSCE, delegated responsibility for supervising elections under Dayton. As part of its programme, the OSCE changed the electoral rules and required 30 percent of the candidates to be women on candidate lists. The measure did increase the number of women representatives in elected bodies. The percentage of women in the House of Representatives leapt up from a miserable 2.38 percent to a much more respectable 26 percent under a closed list system ${ }^{10}$, although the figure dropped back to 14.28 percent when the closed list system was subsequently replaced with an open list system. ${ }^{11}$

Complimentary initiatives seek to enhance the role of women parliamentarians. The remit of the Stability Pact Gender Task Force is to increase 'public awareness of women's political participation in elections and political processes in general; reform existing electoral systems and legislation...to promote women's political participation; establish governmental institutions to promote gender equality.... ${ }^{12}$ A 2001 conference on the theme of Partnership in Parliament - Strategic Steps towards Gender Equality in Sarajevo, for female members of the Parliament, NGO members and others called for 'continuous education' for parliamentarians as well as other measures to encourage women to enter politics. ${ }^{13}$ Grassroots work has been sponsored to enhance women's broader influence on the peace-building and reform process, such as the 'There Are More of Us, Let's Vote' campaign in 1998. The campaign was conducted under the auspices of the League of Women Voters, a coalition of women's NGOs backed by USAID and the OSCE. International organisations gave strong backing to the women's voter education project, although the turnout among women was relatively healthy, especially compared to that of young people. These projects are not simply concerned with ensuring that women vote, but also influencing how women vote by empowering them not to follow their (nationalist voting) menfolk.

How effective is the quota system? The quota system has boosted the number of women standing in Bosnian elections, testifying that women can be politicians and providing role models for other women. Indeed, the idea of quota systems, whether 
gender or ethnically-based, is not an alien concept to Bosnians as elsewhere in Eastern Europe. However, this familiarity with quota systems has made East European electorates more sceptical than international officials or women's NGOs about their impact. 'In the former communist countries...quotas are typically rejected out of hand because they are seen as being parallel to the systems of appointment/election that prevailed under communism', a Stockholm-based research project on gender quotas admits. ${ }^{14}$ Bosnia's own pre-war quota system was widely criticised 'for being merely symbolic' ${ }^{15}$ - because many female politicians owed their position to their connections, their politics tended to simply echo that of their male colleagues. ${ }^{16}$ Similarly, in Britain, the calibre of recent female politicians whose candidatures were secured through quotas has been unfavourably compared to that of their predecessors. Rather than a distinct voice, it was observed that 'Blair's babes', as the 1997 intake were derogatorily named, were less likely to rebel and more likely to tow the government line than their male colleagues, even on matters touching on women's interests. ${ }^{17}$ Strikingly, international reports have commented on the generally poor calibre of female politicians in present-day Bosnia. ${ }^{18}$ Advocates concede some of these criticisms, but argue that quota systems provide professional experience and can therefore help develop their calibre.

However, the stunted nature of political life under international governance is not conducive to improving the calibre of politicians. To focus on the poor calibre of politicial representatives side-steps the degraded nature of the political rights promoted by advocates of quotas. Consider the research by the Stockholm-based Gender Quotas project - which advocates parliamentary gender quotas and increasing women's political participation in Iraq and Afghanistan - while pointedly disregarding the lack of political self-determination in the two states under external regulation. ${ }^{19}$ What political powers do any politicians have when all major policies are made by external powers? The image of re-arranging the deckchairs on the Titanic springs to mind. The weak calibre of Bosnian politicians is unsurprising given the artificial character of Bosnian political life under international governance (see Chandler, this collection). Women's advocates talk about ensuring the meaningful participation of women but without challenging the stunted and restricted nature of politics under international governance. What is the significance of more women becoming members of the Bosnian parliament when local politicians lack real political and legislative powers? Greater political representation, in this case, merely signifies a therapeutic inclusion since Bosnian politicians' role has been reduced to little more than role playing, rubber-stamping internationally determined legislation.

A 'so-called mandatory platform in which political parties have to take positions on the most important, vital issues for all people in $\mathrm{BiH}^{20}$ has been developed by the OSCE in its supervisory role. Over the last decade, not only has opposition to Dayton effectively been outlawed under international governance, but political candidates are expected to adhere to the wide-ranging policies determined by the international community. The, often controversial, reforms such as privatization or pension reforms go far beyond ethnic matters. Consequently, more women becoming politicians in Bosnia under international governance might be better understood as improved employment opportunities for some women rather than women's political empowerment. For all the image of women activists driving gender quotas, their introduction was bound up with the belief of international officials that female politicians would be more amenable than male politicians to international strategies and help legitimise international governance. Tellingly, these sorts of fast track 
gender empowerment approaches are a feature of other weak post-conflict countries under heavy external intervention such as Afghanistan or Rwanda.

International officials hold a rather impoverished and undemocratic view of political participation. The very process of realising the Law on Gender Equality exemplifies how the population is marginalised from policy-making. International organisations were closely involved in drafting the gender equality law at every stage, so much so that even its style reflects how draft provisions spent much of their time being formulated in the English language rather than the language of the country. A snapshot of the process reveals how the Gender Coordination Group discussed a draft which was then 'distributed for review to the International Community and NGOs dealing with the issues contained in the draft' in summer 2001. Only subsequent to this review did the Ministry of Human Rights and Refugees begin organising 'a public debate of the draft law'. ${ }^{21}$ The public became involved following international determination - essentially to be instructed into its provisions. As such, the Law on Gender Equality, as with other such legislation, testifies to the powers of international officials over Bosnian public life rather than the empowerment of Bosnian women.

In this understanding of politics, different social groups are formally represented, but political contest revolves around bureaucratic wrangling over quotas rather than competing political visions. Progressive thinking risks being stifled in the bureaucratic mindset and backroom deals that BiH's gender or ethnic quotas encourage (as was the experience of SFR Yugoslavia). ${ }^{22}$ Since representatives brought through a quota system owe their position to official sponsorship it should be no surprise that the women chosen are those regarded as the most loyal by their sponsors and also prove to be most loyal. Their dependence on official sponsorship rather than popular support predictably encourages quota candidates to take their political cue from their sponsors, whether their sponsorship derives from the main ethnically-based political parties or from the international community. Accountability to the constituency they ostensibly represent is also thereby weakened.

Quota measures risk ossifying representation, institutionalising the position of quota representatives and insulating them from the need to galvanise popular support and address the core concerns of their constituencies. This criticism is particularly relevant to $\mathrm{BiH}$, where a serious dichotomy exists between the gender parity required under the Law on Gender Equality and the social trends for women under international governance, discussed below. Quota systems can undoubtedly advance the position of women's representatives, but whether their advancement necessarily improves the circumstances of ordinary women is a moot point. The feminist political theorist Wendy Brown has warned that identity-based representation can create what she calls 'wounded attachments', a category of representatives with a vested interest in the perpetuation of difference since their own position is premised on their identity's victimized status. ${ }^{23}$ The affirmative action approach of the Law on Gender Equality requiring measures to ensure equal gender representation 'at all levels of government' does not involve any commitment to broader social changes which would enable ordinary women to realise parity of opportunities or of incomes. Arguably the strongest achievement of women's representatives has been securing retention of the gender quota system, i.e., protecting their own positions. They have been less successful in defending maternity provisions and other social rights relevant to ordinary women.

The quota system casts doubt on representation per se, even as it assumes an identity of interests between women. The feminist movement back in the 1970s problematised the idea that the experiences of women, and therefore the interests of 
different groups of women, were the same. Consequently if men cannot represent women's interests, as the gender quota system implies, and women's interests are not identical, how can it be assumed that urban middle class women can best represent the interests of working class or rural women? The Global Rights' 'Shadow Report' observes of women politicians: 'They view the status of all women in $\mathrm{BiH}$ through the lens of their own elevated success or position, and for women politicians in $\mathrm{BiH}$, that status is generally far removed from the position of the average woman in the country. ${ }^{24}$ Again, other social divisions may be more salient, as analysis of women in Bosnia acknowledges. ${ }^{25}$ The limitations of this approach have meant that the potential role of women's organisations in the political empowerment of women has become a central focus.

At first glance, women's involvement in civil society seems much more vibrant and to provide opportunities for women's grassroots activism. Advocates often present women's organisations as activists challenging a reluctant international community to support women's empowerment. More sober reports observe that women run many NGOs, although they have been reluctant to become involved in politics. ${ }^{26}$ Women's organisations have generally been exempt from the critical scrutiny that the rest of the NGO sector has come under during the past decade (see Adam Fagan, this volume). But women's organisations share many of the problems of NGOs in general, although, among researchers, there is a great reluctance to identify these problems, as if to do so would disempower women.

Nevertheless, women's NGOs, like other local NGOs, are essentially orientated towards the international community and reliant on its continuing sponsorship for their survival and evidence a rather weak relation to the population. The observation that the NGO sector is dominated by a small minority of individuals $^{27}$ equally applies to women's NGOs, typically dominated by a small number of individuals from the urban elite. Criticisms of female politicians made by the Global Rights' 'Shadow Report' are relevant to women's NGOs. ${ }^{28}$ NGOs have failed to galvanise popular support among women and have no formal accountability to the population, unlike elected representatives. Without external sponsorship, many local women's NGOs would collapse.

Tensions observed among women's organisations ${ }^{29}$ manifest their reliance on external funds and their need to compete for sponsorship from external donors. Competitiveness between NGOs has been exacerbated by the internationallysponsored NGO sector becoming an important arena of international investment relative to the rest of the economy. This phenomenon has encouraged the emergence of NGO entrepreneurs, or 'anti-war profiteers' as they are nicknamed locally, whose livelihoods depend on the success of their organisation attracting external sponsorship as opposed to another. The proliferation of NGOs is therefore better understood as representing the needs of the urban professional class rather than representing any popular movement. Symptomatically, organisations are disinclined to merge or work together unless cooperating under externally-funded programmes. Even where individuals' involvement transcends these mundane motivations, the general problem remains that NGOs are primarily orientated towards gaining sponsorship from the international community rather than popular support. Indicatively, much of advocates' time is spent writing grant applications to international donors and implementing internationally-sponsored programmes.

Unsurprisingly, the gender policies pursued by women advocates echo those of their international sponsors. Strong views against privatization and new laws reducing social rights exist in the population. Their negative impact on women is 
acknowledged, but there is little evidence that the women's organisations, sponsored by international donors, are opposing these structural adjustment policies which are detrimental to women. The agenda of local women's organisations reflects the international emphasis on cultural and personal change rather than material advancement. Tellingly, the different interests among women, in so far as the problem is acknowledged, are conceptualised essentially in terms of cultural prejudices (urban versus rural), to be addressed by cultural awareness training programmes. Meanwhile, any economic improvements are envisaged as coming about through cultural and personal change. The following section considers these approaches to the economic empowerment of women.

\section{Economic empowerment}

A 1997 ILO report observes that international strategies after the war re-orientated their programming for women 'away from therapy toward income generation, microenterprise and skills training. ${ }^{30}$ Bosnian women had already been trying to use international projects to support income-generating activities. I found this when I visited the Mostar offices of Stope Nade in September 1997. The remit of the internationally-sponsored project ${ }^{31}$ typified the international focus on counselling of female (rape) victims, reproductive health and community peace-building. Local women were adapting its office in eastern Mostar for their own income-generating activities. Instead of encountering counsellors providing women with therapy, I was greeted with a makeup demonstration by a local (Bosniac) Avon lady. Previously, such activities would have been considered supplementary but today many households rely on them as their main income given Bosnia's unemployment. ${ }^{32}$ Likewise international policy-makers increasingly rely on micro-enterprise as the core of their employment strategy, through organizations such Zene za Zene (Women for Women).

Before examining micro-enterprise, I will briefly highlight how microenterprise compliments international structural adjustment policies eroding state employment and welfare provision. ${ }^{33}$ This pattern is evident in Bosnia. Even before the war, women found themselves targeted for redundancy under restructuring programmes on the grounds that their salaries were secondary in the family. State sector employment has been important for women providing not only financial security but also fostering greater social independence as well as associated social benefits such as maternity pay and access to state nurseries. Nevertheless, in the name of promoting 'a more flexible labour market' ${ }^{34}$ and 'reforming provisions that now keep women out of the labour market', ${ }^{35}$ women are losing protections they previously enjoyed such as 'very long maternity leave, prohibitions against their doing night work etc'. ${ }^{36}$ Yet women's NGOs have actually criticised female politicians for focusing 'on maternity legislation and maternity rights as the most important women's issue' and falling into stereotypical women's issues, ${ }^{37}$ despite the pertinence of defending these rights now. The population is expected to lower its expectations and rely on private welfare provision. Human rights lawyers, for example, instruct that the right to health means basic health not up-to-date specialist cancer hospitals - despite the fact that breast cancer is a major killer of Bosnian women. In sum, international economic governance is increasing the social vulnerability of women and the social burden placed on them by authorising the further erosion of state support systems. 
There is a need to rethink international economic governance because of its impact on women and Bosnian society as a whole. International neo-liberal economic policies, requiring the retreat of the state, have failed to regenerate the Bosnian economy to pre-war levels, and are exacerbating social inequalities. ${ }^{38}$ Internationally sponsored privatization policies are fostering 'private affluence and public squalor', in the words of economist J. K. Galbraith. These policies are undermining the state's capacity to raise income through taxation and to regulate the informal economy, in turn undermining its capacity to enforce the rule of law and finance welfare provision. There has been the removal of 'punitive levels of employee-related taxes and welfare provision', i.e., the erosion of employment rights in the private sector. ${ }^{39}$ The privatization programme has thereby reinforced the shadow, ethnicized, patrimonial economic networks, which evolved through the economic crisis and war economy. ${ }^{40}$ World Bank research has found that the informal sector has actually grown in the last couple of years, not shrunk, employing 410,500 people, representing over a third of employment in the country. ${ }^{41}$ Women (and men), unable to rely on state employment or assistance, have had to resort to these shadow patrimonial economic networks as part of their survival strategies. Such patrimonial networks make women more subject to patriarchal relations. In sum, international economic governance implies women being more dependent on kinship ties, despite all its talk of gender policies. At best, gender equality legislation in the current circumstances ensures a fairer distribution of unemployment, social benefit cutbacks and poverty. Few women qualify, for example, for veteran benefits, such as exemptions from health service charges. Furthermore, international policy favours addressing anomalies by taking away benefits rather than expanding eligibility.

International organisations have acknowledged that 'privatising state firms will make things worse' for women, but nevertheless treat privatization as unavoidable. ${ }^{42}$ The ILO report refers to 'the new realities' that Bosnians are having to grasp, ${ }^{43}$ the UNDP argues that privatization 'is necessary and inevitable', ${ }^{44}$ and Global Rights: Partners for Justice accepts privatization 'as an essential aspect of the country's economic reform program' but argues for more women representatives to be included in its implementation. ${ }^{45}$ Alternative economic models, which could give the state a greater role, have not been considered by international policy-makers. ${ }^{46}$ Little love may be lost between BiH's constituent ethnic groups, but one issue that the population is unified over is the role of the state as provider. As international reports observe, "most people still expect "the state" to sort out their problems," 47 as job creator if not welfare provider. ${ }^{48}$ Yet this affirmation of the state and suspicion of the private sector - a potentially powerful resource for state-building based on political and social consensus - tends to be dismissed by international officials as merely backward or outmoded prejudice. This is despite the fact that some rethinking on these questions is evident, even among Western policy-makers who previously advocated privatization and the rolling back of the state. ${ }^{49}$ Alternative economic models, giving a stronger role for the state to create a safety net, would have better protected women's welfare and the social gains women had made since 1945. Interestingly, SFR Yugoslavia managed to reach pre-war growth levels within five years of the end of the Second World War, whereas international officials do not expect $\mathrm{BiH}$ to reach pre-war growth levels until $2010{ }^{50}$ Moreover, even this forecast may be optimistic given current worsening trends. ${ }^{51}$ The 2003 UNDP Annual Report concluded that the current authorities are not offering 'any effective solution to this problem' and that 'the entire country can be considered a "welfare case", even 
allowing for involvement in the informal economy and remittances from relations abroad. $^{52}$

How does the international micro-enterprise approach address these serious economic problems which have hit women disproportionately, particularly femaleheaded households $?^{53}$ Micro-finance has not overlooked women. The World Bank has stated that fifty percent of clients are women. ${ }^{54}$ Indeed in the early years, international reports actually observed how men had difficulty accessing schemes. ${ }^{55}$ Advisers warned that since unemployment affected the majority of the population, micro-credit 'should not be pressed to meet donor demands of heavy concentration on social categories. ${ }^{, 56}$ Over $\$ 30$ million has been invested in two World Bank projects to develop a micro-credit industry in Bosnia, and there have been numerous ad hoc initiatives in addition. The World Bank programme is implemented via government foundations based in the $\mathrm{FBiH}$ and in $\mathrm{RS} .{ }^{57}$ These two foundations have contracted with local micro-credit organisations to administer the loans. Micro-credit organisations receiving contracts have consolidated based on performance. At the end of June 2003, the World Bank reported that 201,421 loans had been distributed with around 51,000 active clients, ${ }^{58}$ a third up from the previous year. ${ }^{59}$ The spread of micro-finance is regionally uneven, but prevalent across both entities. The highest activism is recorded in Podrinje (in RS) and in Sarajevo-Rumenija, Tuzla, and Western Herzegovina (in $\mathrm{FBiH}$ ), involving over 2.5 percent of the population in these four regions. ${ }^{60}$ The average loan was recorded the previous year to be $3,122 \mathrm{KM}$ (£1,050 approximately). ${ }^{61}$ Loans for agriculture and small farming had risen to 39 percent. ${ }^{62}$ Women managed seven out of the thirteen $\mathrm{BiH}$ micro-credit organisations listed as important by the World Bank. ${ }^{63}$

The analysis here is less concerned with questions of access to micro-credit as much as with its centrality to international strategies and how the approach embodies low expectations for the advancement of women. Micro-finance has become important as public sector work has declines while capital investment remains scarce. An ILO/UNHCR micro-finance study admits that micro-finance is about helping people survive, 'the only possible alternative people may turn to in order to earn enough for survival is self-employment through private entrepreneurship'. ${ }^{64}$ However, the future of the small-scale private entrepreneurship envisaged for $\mathrm{BiH}$ is insecure given the population's weak purchasing power and competition from imports. Subsidies or tariffs, which might protect the local market, are eschewed under international economic governance. ${ }^{65}$

Essentially, micro-enterprise represents a shift from state responsibility for employment and a structural understanding of unemployment to an individualized understanding of unemployment, addressing the employability of individuals, i.e., their skills and motivation. Accordingly, the UN Common Country Study for BiH speaks of changing from an economy based on large state industries to one which 'places more responsibility on the shoulders of individual entrepreneurs and workers'. ${ }^{66}$ Micro-credit caught the imagination of international policy-makers as empowering women, building upon the Grameen Bank initiative in Bangladesh. Yet, detailed research on these initiatives suggests that micro-credit has only led to modest gains for women. Indeed, micro-credit is frequently only made available to married women or widows, questioning the idea of micro-credit as emancipating women. ${ }^{67}$ Interestingly, the rates of interest are not necessarily better than those of private lenders, ${ }^{68}$ as is the case in Bosnia. ${ }^{69}$ Micro-credit schemes, providing small capital investment, can only initiate small-scale household production, unless the loans are used to support existing family businesses. In Bosnia, it has been observed that 'the 
impact of micro-finance programs on enterprise development has been greater when people were relatively less vulnerable and had a stronger enterprise to start with' ${ }^{70}$ As a director of micro-finance has advised 'micro-finance alone cannot reduce poverty, it can only supplement a comprehensive development programme'. ${ }^{71}$ Yet micro-credit has become the central employment strategy despite the fact that it only appears to secure the position of women within their existing social roles.

Micro-enterprise, based on small-scale labour-intensive production or gendered service sector work, such as hairdressing, ${ }^{72}$ simply does not address the employment expectations of Bosnian women of working age and instead represents a step backwards. As a joint ILO/UNHCR report states: 'In $\mathrm{BiH}$, the low-income entrepreneur may well be an electronic engineer with twenty years experience'. ${ }^{73}$ Take the generation of women now entering their forties; many are newly poor with a relatively high education level. ${ }^{74}$ This generation, even if they grew up in rural communities, aspired to work in the public sector, whether service provision, administration or public companies, or to set up their own businesses. Related to the latter, there was a certain gendered aspect to those able to start family-sponsored businesses: men would be in charge of cafes (predominantly for male clientele), women would run family shops. They did not desire or expect to remain in labourintensive agriculture or other labour-intensive household production. Such a way of life was viewed as backbreaking, anachronistic and only generating small returns - a fate they wished to escape. Despite these aspirations, the UN Common Country Study for Bosnia suggests that 'it is easy for planners and bankers alike to still aim too high and overlook "micro" enterprise that are often important income sources for womenheaded households'. ${ }^{75}$

Micro-enterprise sounds more glamorous than petty trade, but the latter description is closer to the nature of the activities. The numerous hairdressing or taxi businesses make a scant living as they vie for customers and the purchasing power of the population is 'more than weak, after meeting existential needs' ${ }^{76}$ Moreover, the locally produced goods are often uncompetitive compared to imports, as analysis readily admits. ${ }^{77}$ The returns from small-scale agricultural production are also insecure - women (or their children) competing to sell home-made preserves along the main Sarajevo-Mostar road in the baking heat of summer have few buyers. Likewise, only a limited market exists for the production of handicrafts so beloved by micro-credit advocates. Turnover is visibly slow even for well-established businesses in Bascarsija, the old Turkish commercial district in Sarajevo, competing to sell traditional crafts to international officials as "tourism is practically non-existent ${ }^{78}$. Some projects have sought to train women for work in non-traditional sectors, such as computing. ${ }^{79}$ The focus is still on the employability of individuals, as if unemployment could be addressed merely by middle-aged women acquiring modern skills. In reality, skilled people also lack jobs and (particularly the young) only see a viable future abroad. ${ }^{80}$

Micro-enterprise may work as a coping strategy or a form of occupational therapy, but it does not provide secure employment or advance women's position. As international reports admit, involvement in micro-enterprise is no advancement for the many qualified women who have lost their jobs over the last decade. Interestingly, the World Bank has drastically reduced the figures for employment provided by microfinance from over 180,000 , claimed in $2002,{ }^{81}$ to 100,000 in 2003, despite its dramatic increase in loans. ${ }^{82}$ Failure to generate secure employment perhaps explains why international reports often draw attention to micro-finance's impact on clients' confidence and 'individual and group motivation'. ${ }^{83}$ This emphasis on attitudes rather 
than material circumstances indicates how international policy-makers would rather psychologize social problems.

In contrast to the present post-conflict situation, women experienced unprecedented social gains after the Second World War. Within a decade, large numbers of women, whose mothers had been illiterate and engaged in subsistence farming, went to school and gained employment in the public sector, widening their horizons and challenging the patriarchical extended family structures. Consider the establishment of the huge agricultural processing enterprise Agrokomerc in Kladusa, north-west Bosnia, at one time employing over 13,000 employees, but collapsing in a notorious promissory notes scandal. Whatever criticisms can be levelled at the running of Agrokomerc, it did have a socially transformative impact on women's lives in Kladusa, a poor, isolated region holding very traditional attitudes towards women. Employment at the plant meant entry into the wage economy and experience of work outside the home, giving women new economic and social independence. In turn the factory created new purchasing power and sparked off other businesses in the area to service the wants of Agrokomerc and its employees. Women from Kladusa still nostalgically recall the opening of Agrokomerc's factory and how women's new financial independence enabled them to shake-off their submissiveness and begin challenging their husbands' authority.

In contrast, the petty trading that characterises much micro-enterprise represents a form of disguised unemployment. Unsurprisingly, micro-enterprise lacks the socially transformative impact that the massive expansion of public sector employment had after the Second World War. Instead, social transformation is tagged on, for example, by adding 'a gender awareness and assertiveness component' to skills training and employment promotion programmes. ${ }^{84}$ As a NGO delegate stated at a recent inter-regional conference, held in Srebrenica, on the Law on Gender Equality, 'it is difficult to speak about gender equality when it comes to employment... Here, neither men nor women are successful in finding jobs, for there are none. ${ }^{85}$ Nevertheless, her conclusions emphasised citizen 'education and motivation' and the 'awakening' of women. ${ }^{86}$ Once again, tending to represent issues of social development as being capable of resolution at the psychological level of an individual's attitude towards others and views of themselves.

\section{Conclusion}

In $\mathrm{BiH}$, we are presented with the picture of enlightened internationals struggling to bring progressive gender ideas to an intransigent, backward, patriarchal and abusive culture. If progressive ideas on women are not flourishing in Bosnia, it should be no surprise given that women and men are expected to lower their aspirations in so many aspects of their lives. Gender may legitimise international governance and empower a few female members of the urban elite, but the prospects of advancing the position of ordinary Bosnian women under international governance are illusory.

On the contrary, analysis of international policy-making in this sphere suggests that the emphasis on gender empowerment fits closely with the top-down approach of international policy development. International administrators seem much happier developing policies which are susceptible to bureaucratic target-setting - such as quotas and micro-credit - as opposed to policies capable of generating real changes in the political, social and economic opportunities of Bosnian women.

\section{ACKNOWLEDGEMENTS}


I am grateful to the British Academy for financial assistance towards a visit Bosnia in July 2004. My thanks to David Chandler, Tahera Choudrey and Michael Pugh for encouraging my thinking on international gender policies. However responsibility for the views expressed in this article lies with me.

\section{NOTES}

${ }^{1}$ OHR Sarajevo, 'Support to the Women of BiH on International Women's Day', Office of the High Representative, Press Release, 7 March 2001. Available at: http://www.ohr.int/ohr-dept/presso/pressr/default.asp?content_id=4259.

${ }^{2}$ Gender Centre, Government of the Federation of Bosnia and Herzegovina. Available at: http://www.fgenderc.com.ba/.

${ }^{3}$ Law on Gender Equality in Bosnia and Herzegovina, Official Gazette of BiH, No.16, (2003). Available at: http://www.fgenderc.com.ba/txt/equality_law_in_bh.doc.

4 'Implementation of Gender Equality Law', UNDP Press Release, 4 September 2003. The project has been supported by $\$ 275,000$ from the Government of Japan, $\$ 100,000$ from UNDP and \$25,000 from UNICEF.

5 'The Special Adviser on Gender Issues visits the UN Mission in Bosnia and Herzegovina (UNMIBH)', Network, The UN Women's Newsletter, Vol.5. No.1, March 2001.

${ }^{6}$ OSCE, Women's Representation in Bosnia and Herzegovina: A Statistical Overview 1986, 1990, 1996, 1997. Sarajevo, 1998, cited in M. Walsh, Aftermath: The Role of Women's Organizations in Postconflict Bosnia and Herzegovina, Washington: Center for Development Information and Evaluation / USAID, 2000, p.10. Quota measures had already been used in Bosnia prior to the war and facilitated the relatively impressive figures highlighted here.

${ }^{7}$ International Human Rights Law Group, Women's Rights in BiH. Sarajevo: IHRLG, 1999, p. 182. The Group has since renamed itself Global Rights: Partners for Justice. 
${ }^{8}$ Law on Gender Equality in Bosnia and Herzegovina, (n.3 above).

${ }^{9}$ D. Dahlerup and A. T. Nordlund, 'Gender Quotas: A Key to Equality? A Case Study of Iraq and Afghanistan', European Political Science, Vol.3, No.3, (2004). Available at:

http://www.essex.ac.uk/ECPR/publications/eps/onlineissues/summer2004/research/da hlerup_nordlund.htm.

${ }^{10}$ Figures cited in Walsh, (n.6 above), pp.10-11.

11 Global Rights: Partners for Justice, Shadow Report on the Implementation of CEDAW and Women's Human Rights in Bosnia and Herzegovina, Washington and Sarajevo: January 2004, p.55. Available at: http://www.globalrights.org/resources/BH_shadowreport_cedaw.pdf.

12 'Working table 1: Gender', Stability Pact for South Eastern Europe. Available at: http://www.stabilitypact.org/gender/default.asp.

13 HRCC Human Rights Quarterly Report, 1 April-30 June 2001. Available at: http://www.ohr.int/

${ }^{14}$ Dahlerup and Nordlund, (n.9 above), p.92.

${ }^{15}$ Global Rights: Partners for Justice, (n.11 above), p. 77.

${ }^{16}$ M. Walsh, Post-Conflict Bosnia and Herzegovina: Integrating Women's Special Situation and Gender Perspective in Skills Training and Employment Promotion Programmes, Geneva: ILO, 1997, p.25; Walsh, (n.6 above), p.10.

${ }^{17}$ P. Cowley and S. Childs, 'Too Spineless to Rebel? New Labour's Women MPs', British Journal of Political Science, Vol.33, (2003), pp.345-365.

${ }^{18}$ Walsh, (n.6 above), p.11; Global Rights: Partners for Justice (n.11 above), p.79.

${ }^{19}$ Dahlersup and Nordlund, (n.9 above). 
20 OSCE, 'Women can Change Bosnia.' June 1999. Available at: http://www.oscebih.org/events/events15-7-interview.htm.

${ }^{21}$ HRCC, (n.13 above).

${ }^{22}$ D. Rusinow (ed.) Yugoslavia: A Fractured Federalism, Washington, DC: Wilson Center Press, 1988.

${ }^{23}$ W. Brown, States of Injury: Power and Freedom in Late Modernity, Princeton: Princeton University Press, 1995.

${ }^{24}$ Global Rights: Partners for Justice (n.11 above), p.79.

${ }^{25}$ Walsh, (n.6 above), p.2; Global Rights: Partners for Justice (n.11 above), p.64.

${ }^{26}$ Walsh, (n.6 above), p.8.

${ }^{27}$ D. Chandler, 'Democratization in Bosnia: The Limits to Civil Society-Building Initiatives', Democratization, Vol.5, No.4, (1998).

${ }^{28}$ Global Rights: Partners for Justice (n.11 above), p.79.

${ }^{29}$ Walsh, (n.6 above), p.2.

${ }^{30}$ Walsh, (n.16 above), p.31.

${ }^{31}$ Marie Stopes International was the main international donor.

${ }^{32}$ Walsh (n.16 above), p.10.

33 R. Abrahamsen, Disciplining Democracy: Development Discourse and Good Governance in Africa, London and New York: Zed Books, 2000, p.58.

${ }^{34}$ UNDP, Early Warning System, Bosnia and Herzegovina, Quarterly Report, July September. Sarajevo: UNDP, 2003, p.52. Available at: http://www.undp.ba/publications.asp.

${ }^{35}$ Office of the Resident Coordinator for Development Operations, The Transition to Development - Challenges and Priorities for UN Development Assistance to Bosnia- 
Herzegovina, Common Country Study, Sarajevo: UN Bosnia and Herzegovina, 2000, p.43.

${ }^{36}$ Ibid.

${ }^{37}$ Dahlerup and Nordlund, (n.9 above).

${ }^{38}$ M. Pugh and N. Cooper with J. Goodhand, War Economies in a Regional Context: Challenges of Transformation. A Project of the International Peace Academy, London and Boulder: Lynne Rienner, 2004.

${ }^{39}$ Office of the Resident Coordinator for Development Operations, (n.35 above), p.54. See also Walsh, (n.16 above), p.29.

${ }^{40}$ Pugh and Cooper (n.38 above), pp.170-176.

${ }^{41}$ UNDP, Early Warning System, Annual Report 2003, a Year in Review, Sarajevo: UNDP, 2003, p. 22. Available at: http://www.undp.ba/publications.asp.

${ }^{42}$ Office of the Resident Coordinator for Development Operations, (n.35 above), p.22.

${ }^{43}$ Walsh (n.16 above), pp.11-12.

${ }^{44}$ UNDP, (n.34 above), p.52.

${ }^{45}$ Global Rights: Partners for Justice (n.11 above), p.74.

${ }^{46}$ M. Pugh, 'Liquid Transformation in the Political Economies of $\mathrm{BiH}$ and Kosovo', paper presented at the Seventh International Seminar, Institute for Strengthening Democracy in Bosnia, Konjic, Bosnia, July 2004.

${ }^{47}$ Office of the Resident Coordinator for Development Operations, (n.35 above), p.40.

${ }^{48}$ UNDP, (n.41 above), p.36.

${ }^{49}$ Francis Fukuyama, 'The Art of Reconstruction', The Wall Street Journal, 28 July 2004.

${ }^{50}$ Pugh and Cooper, (n.38 above), p.145.

${ }^{51}$ UNDP, (n.41 above), p.22. 
${ }^{52}$ Ibid, p.33.

${ }^{53}$ R. Kukanesen, Families where Women are Heads of Households, UNDP, May 2003.

54 World Bank Local Initiatives Project, Sarajevo, 2002. Available at: http://siteresources.worldbank.org/INTBOSNIAHERZ/Resources/LIP.pdf.

${ }^{55}$ Walsh, (n.16 above), p.10.

56 N. Goronja, The Evolution of Micro-finance in a Successful Post-Conflict Transition: The Case Study for Bosnia-Herzegovina, Geneva: ILO/UNHCR, 1999, p.16. See also Office of the Resident Coordinator for Development Operations, (n.35 above), p.54.

${ }^{57}$ World Bank Bosnia \& Herzegovina - Micro-finance in Bosnia and Herzegovina, 2004. Available at: http://www.worldbank.org/.

58 World Bank Local Initiatives Project II, Sarajevo, 2003. Available at: http://siteresources.worldbank.org/INTBOSNIAHERZ/Resources/LIP2.pdf.

${ }^{59}$ World Bank, (n.54 above).

${ }^{60}$ World Bank, (n.57 above).

${ }^{61}$ World Bank, (n.54 above).

${ }^{62}$ World Bank, (n.58 above).

${ }^{63}$ World Bank, (n.54 above).

${ }^{64}$ Goronja, (n.56 above), p.8.

${ }^{65}$ Pugh and Cooper (n.38 above), pp.163-169.

${ }^{66}$ Office of the Resident Coordinator for Development Operations, (n.35 above).

${ }^{67}$ A.M. Goetz and R.S. Gupta, Who takes the Credit? Gender, Power and Control over Loan use in Rural Credit Programmes in Bangladesh, IDS Working Paper, No.8. Institute of Development Studies, University of Sussex, 1994; S. White, 
Evaluating the impact of NGOs in rural poverty alleviation. Bangladesh Country

Study. Working Paper, No.50, Overseas Development Institute, London, 1991.

68 Tahera Choudrey, University of Nottingham, private communication with the author.

${ }^{69}$ Goronja, (n.56 above), p.4.

70 M. Matul and C. Tsilikounas, 'Role of Microfinance in the Household Reconstruction Process in Bosnia and Herzegovina', MFC Spotlight Note, No.6, Warsaw: Micro-Finance Centre, 2004, p.8. Available at: http://www.ids.ac.uk/impact/Publications/PartnerPublications/MFC_SN6.pdf.

${ }^{71}$ Interview, 'Bring micro-financing under regulatory body', Daily Star, Dhaka, 28 June 2003.

${ }^{72}$ Walsh (n.16 above), p.32

${ }^{73}$ Goronja, (n.56 above), p.9.

${ }^{74}$ Matul and Tsilikounas (n.70 above), p.3.

${ }^{75}$ Office of the Resident Coordinator for Development Operations, (n.35 above), p.52.

${ }^{76}$ UNDP (n.41 above), p.32; Goronja, (n.56 above), p.17.

${ }^{77}$ Goronja, (n.56 above), p.18. On a recent visit to Konjic, Bosnia, I noticed how IKEA rugs featured among the handicraft items women were selling. Evidently it made more commercial sense to buy ready-made goods to sell than engage in the labour-intensive production oneself!

${ }^{78}$ UNDP, (n.34 above), p.59.

${ }^{79}$ Walsh, (n.16 above), p.36.

${ }^{80}$ Ibid., p.31; UNDP, Are You Part of the Problem or Part of the Solution? Youth in Bosnia and Herzegovina, 2003. Available at: http://undp.ba/publikations.asp

${ }^{81}$ World Bank, (n.54 above). 
${ }^{82}$ World Bank, (n.58 above).

${ }^{83}$ Walsh, (n.16 above), p.31.

${ }^{84}$ ibid., p.37.

${ }^{85}$ Quoted in D. Pelemis, 'Gender Equality in Bosnia and Herzegovina', OSCE Press Release, 9 July 2004.

${ }^{86}$ Ibid. 